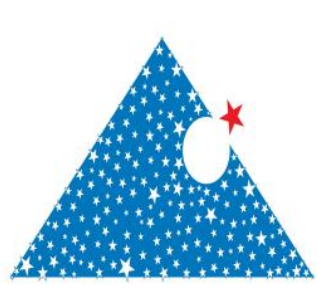

www.dergipark.gov.tr

ISSN:2148-3736

El-Cezerî Fen ve Mühendislik Dergisi

Cilt: 8, No: 2, 2021 (1024-1034)

El-Cezerî Journal of Science and Engineering ECJSE Vol: 8, No: 2, 2021 (1024-1034) DOI : $10.31202 /$ ecjse. 909927

Araştırma Makalesi / Research Paper

\title{
Tam ve Kısmi Kapanma Stratejilerinin COVID-19 Salgını Üzerinden Karşılaştırılması
}

\author{
Mustafa DEMİRBILEK ${ }^{1 a}$ \\ ${ }^{1}$ Gaziantep İslam Bilim ve Teknoloji Üniversitesi, Mühendislik ve Doğa Bilimleri Fakültesi, Endüstri \\ Mühendisliği Bölümü. Gaziantep/TÜRKIYE \\ mustafa.demirbilek@gibtu.edu.tr
}

Received/Geliș: 05.04.2021

Accepted/Kabul: 25.05.2021

\begin{abstract}
Öz: COVID-19 gibi bulaşıcı hastalıkların durdurulması veya en azından bulaşma hızının yavaşlatılıp sağlık sistemine yer ve zaman kazandırılması için kullanılan çeşitli müdahale stratejileri bulunmaktadır. Bunlardan en önemli ve sık kullanılanlarından biri de insanların toplu olarak bulunup, bulaş şansını yüksek oranda artırdıkları okul, iş yeri, alışveriş merkezi, restoran vb. yerlerin belirli süreler için kapatılmasıdır. Kapanmanın kapsamının ve zamanının uygun şekilde belirlenmesi hem vaka sayılarının hem de kapanmanın olumsuz etkilerinin azaltılması bakımından büyük önem taşımaktadır. Bu çalışmamızda, okul ve iş yerlerinin, salgının başlangıcına ve tepe noktasına yakın zamanlarda, tam ve kısmi kapanmasını, vaka sayıları ve toplam kapalı gün sayıları üzerinden karşılaştıracağız. Stratejileri test edeceğimiz salgın, stokastik ağ (network) temelli SIR (KorunmasızHasta-İyileşmiş) ile modellenmiştir. Salgın şiddeti (attack rate), 6 farklı ülkenin aktüel COVID-19 vaka sayılarına göre hesaplanmıştır. Biri baz senaryo olmak üzere, salgının farklı zamanlarında uygulanan tam ve kısmi kapanmaları içeren toplam 5 senaryo, 30'ar koşumda test edilmiş̧ir. Sonuçlara bakıldığında, kısmi kapanmanın tam kapanmaya göre vaka sayılarını önemli ölçüde azalttığı görülmüsstür. Kısmi kapanmada, okul ve iş yerlerindeki kapanma uygulamanın ilk başladığı günden salgının sonuna kadar devam etmesine rağmen, toplam kapalı gün sayısı, tam kapanma sonucu oluşan kapalı gün sayısına göre çok daha düşük çıkmıştır.
\end{abstract}

Anahtar Kelimeler: COVID-19; Stokastik SIR A $\breve{g}$ Modeli; Benzetim; Tam ve Kısmi Kapanma.

\section{Comparison of Complete and Partial Lockdown Strategies on COVID-19 Pandemic}

\begin{abstract}
Some intervention strategies exist to stop or at least slow down spread pace of infectious diseases such as COVID-19 for providing available time and space to healthcare systems. One of most widespread intervention strategies is to shut down some places such as schools, workplaces, shopping malls, restaurants, etc. where individuals crowd and the chance of infection significantly rises for a while. It is really important to determine duration and scope of the closure strategy appropriately to decrease the negative effect of the closure and the number of cases. In this study, we compare full and partial lockdown strategies applied around the beginning and middle of the pandemic in terms of the number of cases and close days. The pandemic we test the strategies is modelled with a stochastic SIR (Susceptible-Infectious-Recovered) network model. The attack rate is calculated based on the number of COVID-19 related cases in six countries. With one baseline scenario, total 5 scenarios generated based full and partial lockdown strategies applied in different times during the pandemic are tested for 30 trials. According to results, the partial lockdown significantly decreases the number of cases compared to the full lockdown. Moreover, the number of closed days for schools and workplaces in the partial lockdown is much lower than the numbers in the full lockdown even though school and workplace closures continue until the end of the pandemic once they start in the partial lockdown.
\end{abstract}

Keywords: COVID-19; Stochastic SIR Network Model; Simulation; Complete and Partial Lockdown.

Bu makaleye atı fyapmak için

Demirbilek, M., "Tam ve Kısmi Kapanma Stratejilerinin COVID-19 Salgını Üzerinden Karșılaștırlması”" El-Cezerî Fen ve Mühendislik Dergisi 2021, 8 (2); 1024-1034.

How to cite this article

Demirbilek, M. "Comparison of Complete and Partial Lockdown Strategies on COVID-19 Pandemic" El-Cezerî Journal of Science and Engineering, 2021, 8 (2); 1024-1034

ORCID ID: ${ }^{\mathrm{a}} 0000-0002-1520-2882$ 


\section{Giriş}

İnsanlık tarihinin başından beri bulaşıcı, hastalıklar toplumları geniş ölçüde etkilemiş, çok sayıda insanın hastalanmasına, ölmesine, göç etmesine ve devletler için büyük ekonomik maliyetlere neden olmuştur. Kıta Avrupa'sını 1346 ve 1353 tarihleri arasında etkileyen hıyarcıklı veba (kara veba) hastalığı, tahminen o yıllardaki nüfusun $\% 30$ ve $\% 60$ arasındaki kısmının ölümüne yol açmıştır. 1918-1920 yılları arasına görülen İspanyol gribi virüsü ise dünya genelinde tahminen 50 milyon insanın ölümüne sebep olmuştur [1]. Daha yakın tarihlerde ise SARS (2003), MERS (2012), Ebola virüsü (2014) dünyanın farklı bölgelerinde görülmüş ve çok sayıda can kaybına ve ekonomik maliyetlere yol açmışlardır.

2019 yılının aralık ayında Çin'in Wuhan şehrinde akut solunum yetmezliğine bağlı olarak kısa zaman içinde birçok hasta yerel hastanelere başvuru yapmaya başlamış, yapılan tetkikler neticesinde bunun yeni ve tehlikeli bir virüs olduğu Dünya Sağlık Örgütü’ne bildirilmiştir. 11 Şubat 2020 tarihinde Dünya Sağlık Örgütü bu yeni virüsü COVID-19 olarak adlandırmıştır. O tarihten bugüne kadar COVID-19 kaynaklı dünya genelinde yaklaşık 115 milyon kişi hasta olmuş, bunlardan 2,5 milyonu hayatını kaybetmiştir. Türkiye'de ise yaklaşık 2,7 milyon kişi hasta olmuş ve şimdiye kadar 28.500 kişi hayatını kaybetmiştir [2]. Yapılan aşı çalışmalarına ve aşılamaların başlamasına rağmen hasta ve ölüm sayısı artmakta, dünya hala ekonomik dar boğazdan çıkamamaktadır.

Bulaşıcı hastalıkların yayılımını durdurmak ya da en azından yavaşlatmak için aşılama, antiviral ilaçlar, okul ve iş yeri başta olmak üzere insanların toplu olarak bulundukları yerlerin kapatılması gibi çeşitli müdahale stratejileri bulunmaktadır. Aşıların ve antiviral ilaçların yokluğunda veya sayılarının sürü bağışıklığına yetecek miktarda olmaması durumunda en çok kullanılan, okul ve iş yerlerinin kapatılarak ev karantinasına geçilmesi yöntemidir. COVID-19 salgınının dünya genelinde ilerlemesine müteakip birçok ülke, okul ve iş yerlerini kapatarak salgının yayılma hızını düşürmeye ve sağlık sisteminde yaşanan yoğunluğu azaltmaya çalışmıştır (Şekil 1). İş yeri ve okulları kapatmak hastalığın yayılmasını azaltan önemi bir strateji olmasına rağmen hem sosyal hem de ekonomik olarak negatif etkileri de bulunmaktadır. Araştırmalara göre bireylerin her zamanki sosyal çevrelerinden kopup, kısmi olarak evlerinde izole olmaları, stres ve depresyona yol açması bakımından bireylerin psikolojisini olumsuz etkilemiştir [3]. Diğer taraftan iş yeri kapatmaları ekonomik açıdan ülkeler için büyük zararlara yol açmıştır [4]. İnsanların evlerine kapanması ve kafe, lokanta, bar gibi iş yerlerinin kapatılması özellikle hizmetler sektöründe büyük daralmaya yol açmıştır. Son olarak her kademede okulların kapatılması ve yüz yüze eğitime geçilmesi eğitim sisteminde aksaklıklara yol açmış, uzaktan eğitim alt yapısı olmayan birçok kurum hızlı değişikliklere ayak uyduramamıştır. Bunun yanında alt sosyoekonomik düzeyde bulunan ailelerde bulunan öğrenciler, hem internete hem de derslerini takip edecekleri teknolojik cihazlara erişimde büyük sıkıntılar yaşamaktadır [5][6].
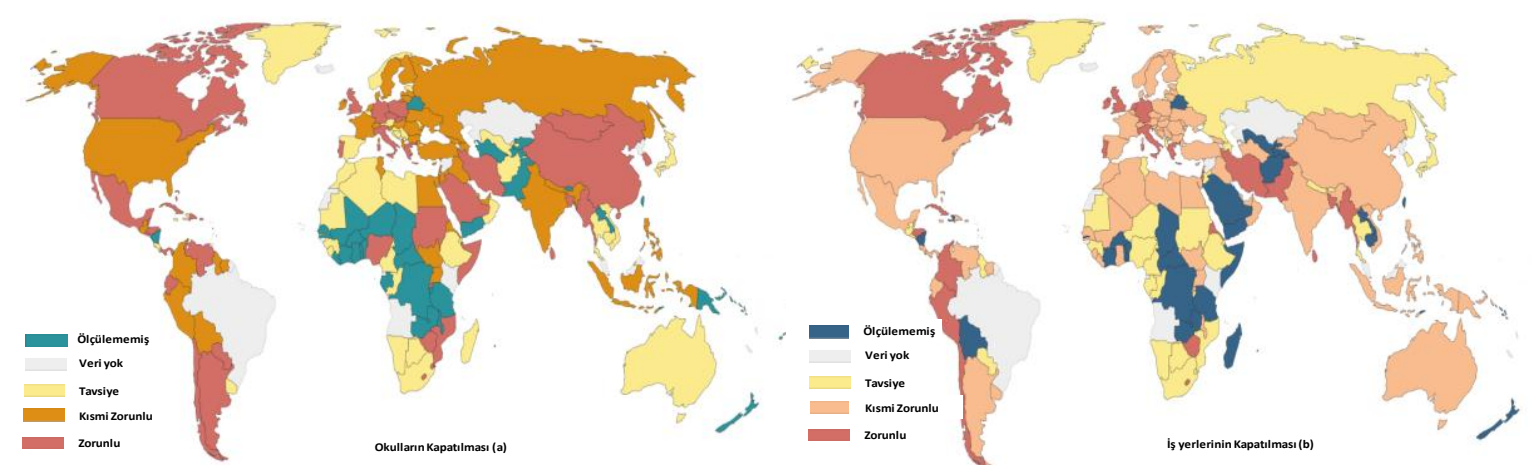

Şekil 1. 1 Mart 2020 tarihi itibariyle dünya genelinde COVID-19 salgınından dolayı okul (a) ve iş yerlerinin (b) kapatılmasıyla ilgili politikalar [7]. 
Okul ve iş yeri kapatmanın kapsamına ve süresine, yukarıda verilen olumsuz durumlar düşünülerek karar verilmelidir. Bir yandan uzun süren tam kapanmalar yukarıda sayılan olumsuz faktörlerin daha da büyümesine neden olurken, diğer taraftan kısa süreli tam kapanmalar veya kısmi kapanmalar salgının yavaşlaması ve durması adına gerekli etkiyi göstermeyecektir. Bu çalışmada, salgının belli zaman aralıklarında uygulanmak şartıyla, tam kapanma ve kısmi kapanmanın vaka sayıları üzerindeki etkisi incelenecektir. Tam kapanmanın uygulanacağı süre boyunca, sistemdeki tüm okul ve işyerleri kapanacak ve buradaki bireyler evlerinde kalacaktır. Kısmi kapanmada ise sadece vaka görülen okul veya iş yeri kapanacak, buradaki bireyler belli bir zaman boyunca evlerinde kalırken, diğer okul ve iş yerleri faaliyetlerine devam edecektir. Hem tam kapanma hem de kısmi kapanma birçok ülke tarafından uygulanıyorken, bunların vaka sayılarına etkileri bakımından karşılaştıran bir çalışmaya rastlanmamıştır.

Herhangi bir salgının modellenmesi, olası vaka sayılarının ve ekonomik etkilerin analizine, aşılama, ilaç, kapanma gibi uygulanmak istenen müdahale stratejilerinin etkinliğine kadar birçok parametrenin ve değişkenin değerlendirilmesine olanak sağlar. Salgınların modellenmesiyle ilgili ilk sistematik çalışma Kermack \& McKendrick [7] tarafından yapılmıştır. Salgınların çeşitli dinamiklerini düşünerek SIR (Korunmasız-Hasta-İyileşen) bölmeli modelini ortaya atmışlar ve hastalığın zamansal değişimini diferansiyel denklemlerle modellemişlerdir. Modelin temel varsayımı, bireylerin bölmeler içinde karışık olarak yer aldığı ve her bir bireyin diğer bireylerle eşit olasılıkla kontak kurabilip, hastalığı yayabildiğidir. Gerçek hayattan bir örnekle ilişkilendirecek olursak, şehrin bir ucunda yaşayan bir bireyin, şehrin diğer ucundaki bir bireyle etkileşime geçme olasılığının, kendi aile ortamındaki bir bireyle etkileşime geçme olasılığı ile aynı olduğunun kabul edilmesidir. SIR bölmeli modelleri, gündelik hayatta kişiler arasındaki etkileşimin genel olarak iş, okul ve aile içerisinde geçmesi durumunu göz önüne almamaktadır. Buna rağmen, büyük popülasyonların hızlı ve doğru biçimde modellenmesinde hala etkili bir yöntemdir [8][9]. Bireylerin çevreleriyle olan yakın etkileşimlerini ağ temelli (network) modeller başarıyla temsil edebilmektedir [10]. Ağ temelli modeller, işgücü piyasasının [11], uluslararası ticaretin [12], finansal piyasaların [13] modellenmesinde sıklıkla kullanılmaktadır. Virüs geçişlerinin örüntüsüne uygun yapısından dolayı, ağ temelli modelleme salgın modellemesi için de kullanılabilir. Bu çalışmada, COVID-19 salgının modellenmesinde ve kapanma stratejilerinin uygulanmasında ă̆ temelli SIR modeli kullanılacaktır. Belli bir büyüklükte popülasyon tanımlandıktan sonra kişiler arasındaki etkileşimler ağ temelli oluşturulacaktır. Çalışmamız kapsamında üç temel ağ, ev, okul ve işyeri tanımlanmış, popülasyondaki her birey belli sayıda bireylerden oluşan bir eve atanmış, ayrıca bireyler yaşlarına göre yine belli sayda bireylerden müteşekkil bir okul veya iş yerine atanmışlardır. Aynı ağda bulunan korunmasız ve hasta bireyler belli zaman aralıklarında birbirleriyle etkileşime geçerek hasta olabilecek ya da hastalığı bulaştırabileceklerdir.

Daha önce bahsedildiği gibi bu çalışmanın konusu olan ağ temelli model üzerinde kısmi ve tam kapanma stratejilerin vaka sayıları üzerinden karşılaştırılmasına literatürde rastlanmamıştır. Fakat hem ağ temelli hem de matematiksel bölmeli modeller, salgın modellemede ve müdahale stratejilerinin uygulanmasında kullanılmışlardır. Matematiksel tabanlı SIR modeller farklı salgınların modellenmesinde ve çeşitli aşı stratejilerinin uygulanıp sonuçlarının analiz edilmesinde kullanılmışlardır [9,16-19]. Bununla beraber ağ temelli modellerle de salgınların modellenmesinde ve kullanıcı ara yüzlü karar destek mekanizmalarının geliştirilmesinde karşılaşılmıştır [20-26]. Bu çalışmadaki ă̆ temelli model, okul, iş yeri ve ev gibi kişilerin etkileşime geçebileceği farklı çevresel yapılar düşünülerek oluşturulmuş, farklı senaryolar büyük popülasyonlar için belli sayıda koşumlarda test edileceğinden, yukarıda bahsedilen diğer ağ temelli modellerin aksine, modelin kompleksliği mümkün olduğunca düşürülmüştür.

\section{Materyal ve Metot}

Bu bölümde öncelikle SIR temelli ağ modelleri üzerinde durulacak daha sonra ise benzetim için gerekli olan veriler ve parametreler açıklanacaktır. 


\subsection{SIR Tabanlı Ăg Modelleri}

SIR, sırasıyla korunmasız (susceptible), hasta (infectious) ve iyileşmiş (recovered) kelimelerinin, ingilizce karşılıklarının baş harflerinden oluşmaktadır. Korunmasızlar popülasyon içinde hastalığa henüz yakalanmamış bireyleri oluştururken, hastalar enfekte olmuş kişilerdir. Korunmasız ve hasta bireyler arasında oluşan etkileşim korunmasız kişilerin hasta olmasına ve bundan sonraki etkileşimlerinde korunmasız bireyleri hasta yapma özelliği kazanmalarına neden olur. Hasta olan bireyler belirli bir iyileşme periyodundan sonra ya iyileşip sonraki süreç boyunca hastalanmaz ve kimseye hastalığı bulaştıramazlar ya da ölürler. Matematiksel SIR modellerde, popülasyondaki korunmasız bireylerin birim zamanda hasta bireylerle etkileşime geçme ve hasta olma, ölüm ve iyileşme durumları diferansiyel denklemlerle matematiksel olarak ifade edilir ve çözülür. Gerçek hayatta, bireylerin kontak kurduğu kişi sayısı sınırlıdır ve homojen değildir. Matematiksel SIR modeller bunu göz ardı etmesine rağmen, büyük popülasyonların hızlı ve doğru biçimde modellenmesinde hala etkili bir yöntemdir. SIR tabanlı ă̆ modellerinde ise bireylerin sadece çevresindeki (ağındaki) bireylerle etkileşim halindedirler. Bu çevre kişinin yaşadığı ev, devam ettiği okul veya çalıştığı iş yeri, alışveriş yaptığı mağazalar, kullandığı toplu taşıma araçları olabilir [27]. Bireyler, belirli zaman aralıklarında tanımlanmış çevrelerindeki diğer bireylerle etkileşime geçip, korunmasızlarsa hasta olabilirler, hastalarsa çevrelerindeki korunmasız bireyleri hasta edebilirler. Bireylerin çevresindeki bireylerle direkt bağlantısı bulunuyorken, çevresinde (ağında) olmayan bireylerle indirekt bağlantısı bulunabilir [27]. Örnek olarak bir evde sürekli olarak bulunan 65 yaş üstü bir birey, aynı evde yaşadığı okul çağındaki başka bir bireyle direkt bağlantılıyken, okula giden bireyin sınıf arkadaşlarıyla indirekt bağlantı kurmuş olur. Yani sınıfta hasta bireyler olması, evi paylaştığı genç bireyin hastalanmasına ve sonunda yaşlı bireyin bu genç bireyden hastalığı kapmasına neden olabilecektir. Matematiksel SIR modellerdeki, popülasyondaki tüm bireylerin homojen etkileşim varsayımının aksine, SIR ağ modellerinde bireyler arasındaki etkileşim direkt ve indirekt olarak tanımlanır.

$\mathrm{Bu}$ çalışmada popülasyonda tanımlı bireylerin yaşlarına göre etkileşime girebilecekleri, ev, okul ve iş yeri olmak üzere üç farklı çevre tanımlanmıştır. Popülasyondaki her bir birey, bir eve atanmak zorundadır. Bireylerin yaşlarına göre bir okul veya bir iş yerine atanabilir veya evlerinde kalabilirler (yaşlılar, küçük çocuklar, işsizler, vb.). Modelde her bir gün, iki zaman dilimine ayrılmıştır. Birinci zaman diliminde kişiler sadece atandıkları evlerdeki diğer kişilerle etkileşime geçebilirler. Günün ikinci zaman diliminde ise bireyler atandıkları okul veya iş yerine hareket eder. Aynı şekilde okul veya iş yerine beraber atandıkları bireylerle etkileşime geçip hasta olabilirler veya hastalığ bulaştırabilirler. Evde kalmak zorunda olan bireyler ise eğer evde başka bireyler varsa günün ikinci zaman diliminde onlarla etkileşime geçerler. Yukarıda anlatılanlar Şekil 2'de illüstre edilmiştir.

Korunmasız bir kişinin, bir zaman diliminde hasta olma olasılığı, pb, Eşitlik 1'deki gibi hesaplanmaktadır.

$$
p b=1-p^{n}
$$

Burada $p$ hastalığın bulaşma şiddetine (attack rate) göre kalibre edilir ve 0-1 arasında bir değer alır. Kişinin bulunduğu ağdaki hasta kişi sayısını ifade eden $n$ sayısının büyüklüğü ve küçüklüğü, hasta olma olasılığını doğrudan etkiler. Hasta olma olasılığ hesaplandıktan sonra 0 ve 1 arasında rasgele bir sayı üretilir. Eğer bu sayı hesaplanan olasılığa eşit veya olasılıktan küçük ise kişi hastalanır. Değilse korunmasız olarak devam eder. Hasta olan her bireye daha sonra açıklanacağı aralıklarda bir iyileşme süresi atanır. Bu süre sonuna kadar kişi, çevresindeki bireyleri hasta etmeye devam eder. Hastalanma olasılığı sadece korunmasız bireyler için hesaplanır. 

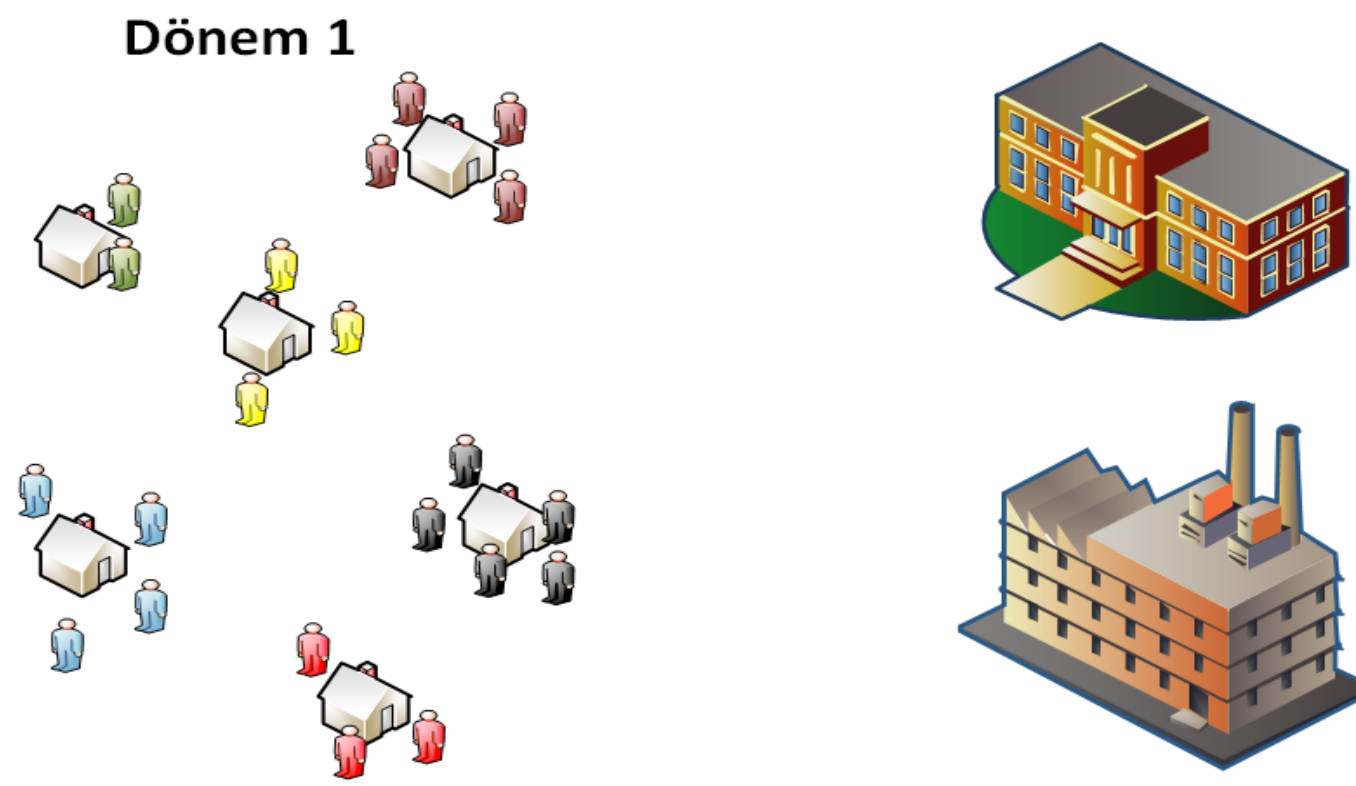

\section{Dönem 2}
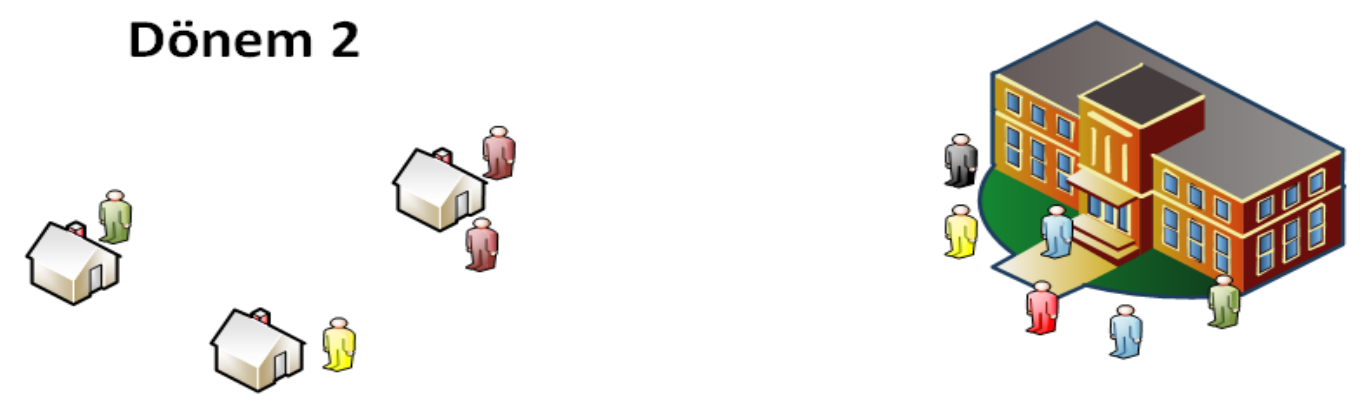

खी
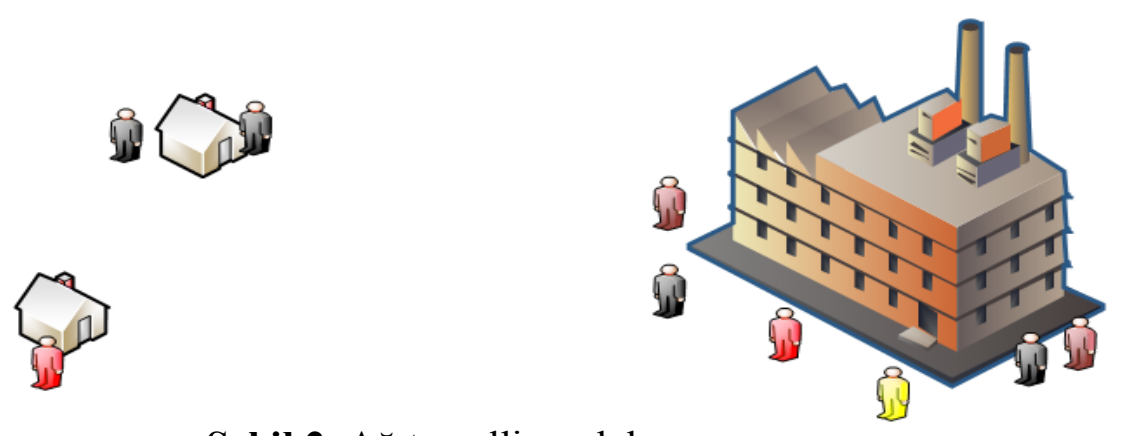

Şekil 2. A $\breve{g}$ temelli model

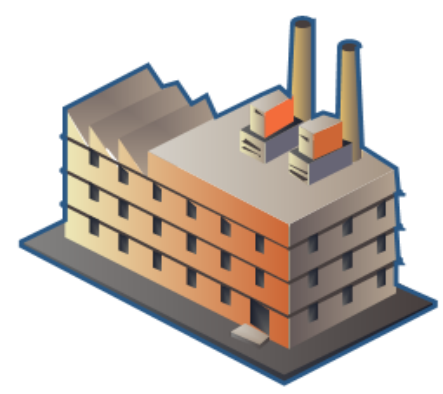

\subsection{Benzetim Verileri}

Çalışmamızda 120 günlük salgın süresi düşünülmüştür. Salgının tepe yaptığı nokta salgın süresinin ortaları yani 58-62 gün aralıklarıdır. Bir milyon bireyden oluşan popülasyon, 0-4, 5-19, 20-24, 2559,60 ve üstü olmak üzere 5 yaş grubuna bölünmüştür. $0-4$ ve 60 üstü yaş grubunda olan bireylerin çalışmadıkları ve günlerinin çoğunu evde geçirdikleri varsayılmıştır. 5-19 yaş grubundaki bireylerin, ilk, orta ve lise çağındaki öğrencilerini temsil ettiği, 20-24 yaş aralı̆̆ındaki bireylerin ise \%70'inin öğrenci olduğu, geriye kalanların bir iş yerinde çalıştı̆̆ kabul edilmiştir. 25-59 yaş grubundaki bireyler asıl çalışan grubu oluşturmakta, bunların \%88'inin aktif olarak çalıştığı, geriye kalanların işsiz olduğu ve zamanlarını evde geçirdikleri varsayılmıştır. Veriler, TÜíK'in 2019 raporları temel alınarak oluşturulmuştur. Tamamen korumasız bir popülasyonda, birim zaman içerisinde hasta olan bireylerin, başlangıçtaki korunmasız birey sayısına oranını gösteren hastalığın bulaşma şiddeti (attack rate), hem Tablo 1'deki gibi 6 farklı ülkenin COVID-19 vaka sayıları kullanılarak hesaplanmış $(\% 7,2)$ hem de vaka sayılarının, devletler tarafından uygulanan çeşitli 
müdahale stratejileri neticesinde düşük olduğu değerlendirilerek, \%15 kabulüyle benzetim içinde kullanılmıştır.

Tablo 1. Hastalığı bulaşma şiddeti ve vaka sayıları bazlı ölüm oranlarının 6 ülkenin COVID-19 vaka sayılarına göre hesaplanması [2]

\begin{tabular}{lllllc}
\hline \multicolumn{1}{c}{ Ülke } & Nüfus & Vaka & $\begin{array}{c}\text { Bulaştırma } \\
\text { Şiddeti }\end{array}$ & $\begin{array}{c}\text { Ölümlü } \\
\text { Vaka }\end{array}$ & $\begin{array}{c}\text { Ölüm/Hasta } \\
\text { Oranı }\end{array}$ \\
\hline ABD & 331.002 .651 & $\mathbf{2 9 . 8 6 2 . 1 2 4}$ & 0,090 & $\mathbf{5 4 2 . 1 9 1}$ & 0,018 \\
Almanya & 83.783 .942 & $\mathbf{2 . 5 3 2 . 8 5 5}$ & 0,030 & $\mathbf{7 3 . 2 7 6}$ & 0,029 \\
İngiltere & 67.886 .011 & $\mathbf{4 . 2 3 4 . 9 2 4}$ & 0,062 & $\mathbf{1 2 4 . 9 8 7}$ & 0,030 \\
Fransa & 65.273 .511 & $\mathbf{3 . 9 6 3 . 1 6 5}$ & 0,061 & $\mathbf{8 9 . 5 6 5}$ & 0,023 \\
İspanya & 46.754 .778 & $\mathbf{3 . 1 7 8 . 4 4 2}$ & 0,068 & $\mathbf{7 1 . 9 6 1}$ & 0,023 \\
İtalya & 60.461 .826 & $\mathbf{3 . 1 2 3 . 3 6 8}$ & 0,052 & $\mathbf{1 0 0 . 8 1 1}$ & 0,032 \\
Hesaplanan Oranlar & $\ldots$ & $\mathbf{\ldots}$ & $\mathbf{\% 7 , 2}$ & $\mathbf{. .}$ & $\mathbf{\% 2 , 1}$ \\
\hline
\end{tabular}

Yukarıda belirtildiği gibi $p$ değeri hastalığın bulaşma şiddeti olan \%7,2 ve \%15 değerlerine göre kalibre edilmiştir. İyileşme süreleri her birey için aynı olup, 6 ve 9 gün arasında düzgün dağılıma sahiptir. Her benzetim rasgele olarak seçilmiş 15 hasta bireyle başlamaktadır. Evlerdeki birey sayısı 1 ve 7 , iş yerlerindeki birey sayısı 50 ve 100 ve son olarak okullardaki birey sayısı 290 ve 310 arasında düzgün olarak dağılmıştır. Benzetim ile ilgili gerekli veriler Tablo 2'de özet olarak gösterilmiştir.

Tablo 2. Benzetim verileri ve senaryolar

\begin{tabular}{ll|ll}
\hline Bulaşma Şiddeti & $\% 7,2-\% 15$ & İş Yeri (kişi) & Düzgün (50,100) \\
Ölüm Oranı & 0.021 & Senaryo 1 & 2. hafta da tam kapanma \\
Popülasyon (milyon) & 1 & Senaryo 2 & 2. haftadan sonra kısmi kapanma \\
Başlangıç Hasta Sayısı & 15 & Senaryo 3 & 8. hafta da tam kapanma \\
İyileşme Süresi (gün) & Düzgün $\sim(6,9)$ & Senaryo 4 & 8. haftadan sonra kısmi kapanma \\
Ev (kişi) & Düzgün $\sim(1,7)$ & Baz Senaryo & Hiçbir önlem almamak \\
Okul (kişi) & Düzgün $\sim(290,310)$ & Kapanma (Gün) & 14 \\
\hline
\end{tabular}

$\mathrm{Bu}$ çalışma için Tablo 2'de gösterildiği gibi kısmi ve tam kapanma stratejilerini ve kapanma zamanlarını içeren 4 farklı senaryo düşünülmüştür. Senaryo 1 ve 3 'te, 2. ve 8 . hafta başlarından itibaren 14 günlük tam kapanma stratejisi test edilmiştir. 120 günlük salgın süresi düşünüldügünde kapanma zamanları salgının başlarına ve ortalarına denk gelmektedir. Burada amaç, salgının farklı zamanlarında uygulanan müdahale stratejilerinin, vaka sayılarını nasıl etkilediğini gözlemlemektir. Tam kapanma boyunca okul ve iş yerlerindeki tüm bireyler zamanlarını evde geçirmek zorundadır. $\mathrm{Bu}$ yüzden sadece evlerindeki diğer bireylerle etkileşime geçebilecek; bunun sonucunda hasta olabilecek veya hastalığı yayabilecektir. 14 günün sonunda bireyler okullarına ve iş yerlerine gitmeye devam edeceklerdir. Kapanmanın 14 gün olarak belirlenmesinin nedeni, Türkiye'de ve dünyanın pek çok ülkesinde bilim kurullarının veya uzmanların en az 2 haftalık tam kapanma tavsiyeleridir. Kısmi kapanmada ise bir okul veya iş yerinde hasta bir bireye rastlandığ zaman o okul veya iş yeri 14 gün boyunca kapatılmaktadır. Diğer okul ve iş yerleri bu kapanmadan etkilenmemektedir. Kısmi kapanmalara, senaryolara göre 2. ve 8. haftalarda başlanabilir. Tam kapanmadan farklı olarak kısmi kapanmalar başladıktan sonra salgının sonuna kadar devam etmektedir. Bununla tam ve kısmi kapanma sırasında, okul ve iş yerlerinin kapalı gün sayısı ve toplam vaka sayılarına etkisi ölçülecektir. Senaryolardaki kapanma süreleri iki farklı salgın şiddeti içinde aynı şekilde uygulanacaktır.

Şekil 3'te salgının benzetim modelinin sözde kodu verilmiştir. Öncelikle salgının yaşanacağı popülasyon TÜİK verilerine göre üretilip, bireyler yaş gruplarına göre evlere, okullara ve iş 
yerlerine atanmaktadır (Satır 1-2). Daha sonra senaryolar, koşum sayıları ve salgın sürelerine göre atanmaktadır (Satır 3-5). Tanımlı olan her senaryo için 30 koşum yapılmakta, her koşum için 120 günlük salgın periyodu farklı rassal parametrelerle test edilmektedir. Salgın boyunca her gün, bireyler Şekil 2'te gösterildiği gibi öncelikle kendi hane halkıyla etkileşime geçip, hastalığın yayılmasına neden olacaklardır (Satır 10).

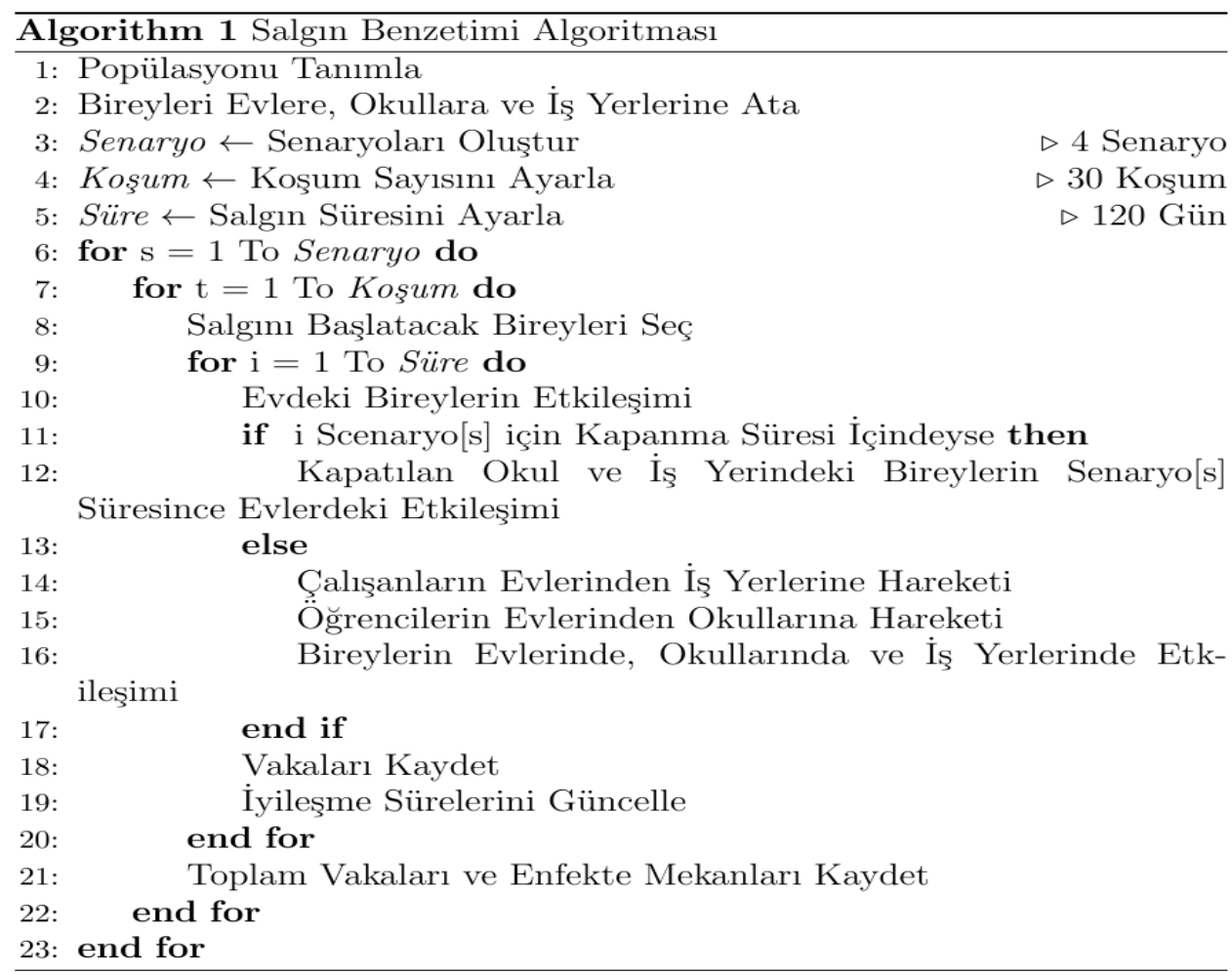

Şekil 3. Salgın benzetimi sözde kodu (pseudo code)

Eğer süreç içerisinde bir gün kapanma zaman aralıklarına denk gelirse, senaryoya bağlı olarak tam kapanmada bütün iş yerleri ve okullara, kısmi kapanmada ise sadece hastalığın tespit edildiği iş yerleri ve okullara atanmış bireyler, o gün sadece bulundukları evlerdeki bireylerle etkileşime geçebilecekler, sağlık durumlarına göre hasta olabilecek veya hastalığ 1 evlerindeki diğer bireylere bulaştırabilecekler (Satır 11-13). Eğer kapanma hali söz konusu değilse, okullardaki, iş yerlerindeki ve evlerdeki bireyler kendi ağlarında bulunan diğer bireylerle etkileşime geçip, hasta olabilecekler ya da hastalığı yayabileceklerdir (Satır 14-16). Günün sonunda oluşan vakalar kaydedilecek ve yeni hastalar için iyileşme zamanı atanırken, eski hastalar için iyileşme zamanları güncellenecektir (Satır 18-19). Her koşumun sonunda toplam vaka sayıları ve enfekte olan okul, iş yeri ve evlerin kayıtları tutulmaktadır.

Çalışmamızda ağ yapılarının oluşturulması, bireylerin etkileşim sonunda hasta olup olmayacaklarının belirlenmesi, iyileşme zamanlar vb. gibi faktörler stokastik olduğundan, tek koşumdan sonra ortaya çıkacak sonuçların birbirleriyle karşılaştırılması istatiksel açıdan doğru olmayacaktır. Bu yüzden her senaryo için 30 koşum yapılmış, sonuçlar arasındaki farklılıkların istatistiksel olarak anlamlılıkları bağımsız gruplar $t$ testleriyle ölçülmüştür. Modelimiz Python programlama diliyle kodlanmış, bütün koşumlar Intel i5 7200U $2.5 \mathrm{GHz}$ işlemcili ve $8 \mathrm{~GB}$ belleğe sahip Windows 10 işletim sistemi kurulu bir bilgisayarda gerçekleştirilmiştir.

\section{Bulgular ve Tartışma}

Tablo 3 ve 4 'te sirasıyla 6 farklı ülkenin COVID-19 kaynaklı vaka sayıları kullanılarak hesaplanan salgın şiddeti $(\% 7,2)$ ve herhangi bir müdahale olmadan oluşabilecek salgın şiddeti $(\% 15)$ için 
modellenen salgına bağlı hasta ve ölü sayıları, 30 koşum için hesaplanan \%95 güvenilirlikteki aralık değerleri (GA) ve senaryolara bağlı okul ve iş yerleri için kapatılan gün sayıları verilmiştir. COVID-19 kaynaklı vaka sayılarından hesaplanan salgın şiddeti değerine göre salgının modellendiği durumda her senaryo için ortaya çıkan sonuçlar Tablo 3 'te gösterilmiştir. Öncelikle herhangi bir müdahale stratejisinin uygulanmadığı baz senaryo için toplam hasta sayısı yaklaşık 70.000 olarak ortaya çıkmıştır. Bir milyon nüfus için \%7,2'lik bir salgın şiddeti düşünüldüğünde beklenen hasta sayısı 72.000 olacaktır. \%95 güvenilirlikte hesaplanan aralıkları düşündügümüzde (3.801), beklenen değerin hesaplanan aralıklara düştügünü görebiliriz. Senaryo 1 ve 2'de uygulanacak tam ve kısmi kapanma stratejilerinin, salgının başlamasından iki hafta sonra uygulanmaya başlaması test edilirken; Senaryo 3 ve 4'te stratejiler salgının başlamasından 8 hafta sonra, yaklaşık salgının tepe yaptığı zamanlarda test edilmiştir. Sonuçları bu bağlamda değerlendirdiğimizde, hangi strateji olursa olsun, erken uygulamaya başladığımızda vaka sayılarının önemli ölçüde azaldığınız görebiliriz. Modele göre eğer tam kapanma stratejisi ilk iki haftadan sonra uygulanmaya başlanırsa vaka sayılarını yaklaşık \%46, kısmi kapanma stratejisi ilk iki haftadan sonra uygulanmaya başlanırsa vaka sayılarını yaklaşık \%70 oranında azaltacaktır. Diğer taraftan salgının 8. haftasından itibaren stratejileri uygulamaya başladığımızda, 2 haftalık tam kapanmanın vaka sayılarını azaltmada pek etkili olmadığını; kısmi kapanmada ise vaka sayıları baz senaryoya göre \%25 civarında azalmasına rağmen, erken uygulanmasıyla karşılaştırdığımızda etkisinin ciddi şekilde düştügünü gözlemleyebiliriz. Tam ve k1smi kapanma yöntemlerini karşılaştırdığımızda, kısmi kapanmanın erken veya geç uygulanmasına göre fark etmeksizin, tam kapanmaya göre vaka sayılarını önemli ölçüde düşürmüştür. Daha önce bahsedildiği gibi tam kapanma durumunda bütün okul ve iş yerleri 14 gün boyunca kapalı kalacak ve bireyler bu süreyi evlerinde geçirecektir. Kısmi kapanmada ise sadece hasta bireylerin ortaya çıktığı okul ve iş yerleri 14 gün boyunca kapanacak, diğer yerler aktivitelerine devam edecektir. Fakat kısmi kapanmada süreç salgın sonuna kadar devam edecektir. Burada en önemli soru, kısmi kapanma sonucu okul ve iş yerleri için günlük kayıların, tam kapanma sonucu oluşacak kayıplara göre fazla olup olmadığıdır.

Tablo 3. 6 farklı ülkenin COVID-19 kaynaklı vaka sayıları kullanılarak hesaplanan salgın şiddeti $(\% 7,2)$ için modellenen salgına bağlı hasta ve ölü sayıları, 30 koşum için hesaplanan \%95 güvenilirlikteki aralık değerleri (GA) ve senaryolara bağlı okul ve iş yerleri için kapatılan gün say1lar1.

\begin{tabular}{ccccccc}
\hline Senaryo & Hasta & GA \%95 (+/-) & Ölü & GA \%95 (+/-) & Okul (Gün) & $\begin{array}{l}\text { Işs } \\
\text { (Gün) }\end{array}$ \\
\hline Baz & 69.983 & 3.801 & 1.647 & 89 & 0 & 0 \\
$\mathbf{1}$ & 37.574 & 4.350 & 878 & 101 & 13.440 & 80.864 \\
$\mathbf{2}$ & 19.748 & 953 & 462 & 25 & 2.051 & 7.918 \\
$\mathbf{3}$ & 62.211 & 3.542 & 1.474 & 85 & 13.440 & 80.864 \\
$\mathbf{4}$ & 52.319 & 2.851 & 1.244 & 70 & 576 & 3.212 \\
\hline
\end{tabular}

Tam kapanmada bütün okul ve iş yerleri 14 gün boyunca kapalı kalacağı için, toplam okul ve iş yeri sayısını 14 ile çarparak kapalı gün sayısını Tablo 3'te görüleceği gibi hesaplayabiliriz. Kısmi kapanmada ise stratejinin uygulanmaya başladığ 1 günden salgının sonuna kadar kapatılan okul ve iş yeri sayısını 14 gün ile çarparak toplam kapalı gün sayısı tablodaki gibi hesaplanmıştır. Tam kapanmayla kıyaslandığında vaka sayılarını önemli oranda düşüren kısmi kapanma stratejisi, aynı zamanda çok daha az sayıda okul ve iş yerinin kapanmasına neden olmuştur. Tablo 4'te, \%15 salgın şiddeti için modellenen salgına bağlı hasta ve ölü sayıları, 30 koşum için hesaplanan \%95 güvenilirlikteki aralık değerleri ve senaryolara bağlı okul ve iş yerleri için kapatılan gün sayıları verilmiştir. \%15 salgın şiddeti ve bir milyon nüfus için salgın sonunda beklenen hasta sayısı 150.000 kişidir. Güven aralıkları düşünüldüğünde beklenen değerin hesaplanan aralıklara düştüğünü söyleyebiliriz. Yüksek salgın şiddetinde de önceki duruma benzer şekilde müdahale 
yöntemlerine erken başlanmasının vaka sayıları üzerinde oldukça etkili olduğu görülmüştür. Tam kapanma baz senaryoya göre vaka sayılarını yaklaşı \%33 azaltırken bir önceki senaryoda azalış \%46 olmuştur. Kısmi kapanmaya baktığımızda yaklaşık \%72 azalma ile bir önceki senaryoya yakın oranlar görmekteyiz. Aynı şekilde salgının başlamasında 8 hafta sonra uygulanan kısmi kapanma stratejisi bir önceki senaryoya benzer şekilde vaka sayılarını \%27 azaltmıştır. Okul ve iş yerlerinin kapalı kaldığı toplam gün sayılarına bakarsak tam kapanma stratejisi için bir önceki durumla aynı olduğu Tablo 4'te görülecektir. Bunun sebebi nüfus değişmediği için modelde oluşturulan okul ve iş yeri sayısı iki durumda da sabittir. Kısmi kapanma durumunda ise beklendiği gibi daha yüksek salgın şiddetinde kapanan okul ve iş yeri sayısının ve buna bağlı olarak toplam kapalı geçirilen gün sayısının arttığı görülmektedir. Bu artışa rağmen kısmi kapanma sırasında ortaya çıkan kayıp gün sayısı, tam kapanma sırasında okul ve iş yerlerinin kapandığı toplam gün sayısıyla kıyaslandığında hala çok düşüktür.

Tablo 4. \%15 salgın şiddeti için modellenen salgına bağlı hasta ve ölü sayıları, 30 koşum için hesaplanan \%95 güvenilirlikteki aralık değerleri (GA) ve senaryolara bağlı okul ve iş yerleri için kapatılan gün sayıları.

\begin{tabular}{ccccccc}
\hline Senaryo & Hasta & GA \%95 (+/-) & Ölü & GA \%95 (+/-) & Okul (Gün) & İş Yeri (Gün) \\
\hline Baz & 157.124 & 10.368 & 3.707 & 247 & 0 & 0 \\
$\mathbf{1}$ & 105.191 & 7.513 & 2.460 & 177 & 13.440 & 80.864 \\
$\mathbf{2}$ & 41.733 & 1.145 & 996 & 26 & 3.176 & 9.320 \\
$\mathbf{3}$ & 134.818 & 6.375 & 3.171 & 154 & 13.440 & 80.864 \\
$\mathbf{4}$ & 115.460 & 6.441 & 2.733 & 148 & 944 & 4.443 \\
\hline
\end{tabular}

\section{Sonuç ve Öneriler}

Bulaşıcı hastalıklar, insanlık tarihi boyunca dünyanın hemen her köşesindeki birçok toplumu etkilemiş, çok sayıda insanın hasta olmasına, ölmesine, ekonomik kayıplara neden olmuştur. SARS, MERS, eboladan sonra 2019 Aralık ayından beri COVID-19 virüsü hem ülkemizde hem de dünyada çok sayıda insanın hayatını kaybetmesine ve büyük ekonomik kayıplara neden olarak, 21. yüzyılın en önemli salgınlarından biri olarak adını yazdırmıştır. Bulaşıcı hastalıkların yayılmasının önlenmesi ya da en azından hızının yavaşlatılıp sağlık sistemlerinin tıkanmaması için aşı, antiviral ilaçlar, insanların toplu olarak bulunduğu yerlerin kapatılması gibi çeşitli müdahale yöntemleri bulunmaktadır. Özellikle etkili aşı ve antiviral ilaçların yokluğunda en çok kullanılan yöntem, bireylerin toplu olarak bulunduğu okul, iş yeri, alışveriş merkezleri gibi yerlerin kapatılıp, bireylerin mümkün olduğunca izole edilmeleridir. $\mathrm{Bu}$ kapatmalar, belirlenen tüm yerlerin bir süreliğine tümüyle kapanmasıyla uygulanabileceği gibi, sadece vakaların göründüğü yerlerin kapanmas1 şeklinde de uygulanabilir. Bu çalışmada, tüm okul ve iş yerlerinin belirli bir süre kapanmasını kapsayan tam kapanma yöntemi ile sadece vaka görülen okul ve iş yerlerinin kapanmasını kapsayan kısmi kapanma yöntemi, vaka ve okul/işyeri kapalı gün sayıları üzerinden karşılaştırılmıştır. TÜIIK verilerine göre 5 farklı yaş grubunun düşünüldüğü bir milyonluk bir popülasyon ile 120 gün olarak modellenen salgın sürecinin, ilk iki haftasından ve yaklaşık tepe yaptığı ortalarından başlamak üzere iki farklı zamanda tam ve kısmi kapanma stratejileri uygulanmıştır. Hiçbir müdahale stratejinin olmadığı baz senaryoda vaka sayıları, hem 6 farklı ülkenin halihazırdaki vaka sayılarına göre hesaplanan \% 7,2'lik salgın şiddetine hem de şimdiye kadar uygulanmış ve vaka sayılarında belirli oranlarda düşüş yaratmış farklı müdahale yöntemlerinin olmadığı bir durumun düşünüldügü \%15'lik salgın şiddetine göre kalibre edilmiştir. Salgının modellenmesinde ă̆ (network) modeli kullanılmış, popülasyondaki bireyler yaşlarına göre okul ve iş yerlerine atanmış, günün bir bölümünde sadece evlerindeki bireylerle etkileşime geçebilirken; diğer bölümünde ise atandığı okul veya iş yerindeki bireylerle etkileşime geçmesi sağlanmıştır. Bu etkileşimler sonucu korunmasız bireyler, belirli bir olasılıkla çevresindeki bireylerden hastalık kapabilirken; hasta bireyler, iyileşene 
kadar korunmasız bireyleri enfekte edebilmektedir. Hasta bireyler, belirli bir iyileşme periyodundan sonra sağlıklarına kavuşabilmekte veya ölebilmektedirler.

Baz senaryo dahil, iki farklı zamanda uygulanan tam ve kısmi kapanma stratejilerini içeren 5 senaryo bulunmaktadır. Stokastik benzetim yapıldığından sonuçların arasındaki farkın istatistiksel olarak anlamlı olup olmadığını anlamak adına, her senaryo için 30 koşum yapılmış ve \%95 güvenilirlik düzeyinde aralık değerleri hesaplanmıştır. Sonuçlara bakıldığında, hem \%7,2'lik hem de \%15'lik salgın şiddeti için kısmi kapanmanın tam kapanmaya göre vaka sayılarını önemli ölçüde azalttığ1 görülmüştür. Kısmi kapanmada, okul ve iş yerlerindeki kapanma uygulamanın ilk başladığ1 günden salgının sonuna kadar devam etmesine rağmen, okul ve iş yerleri için kapalı gün sayısı, tam kapanma sonucu oluşan kapalı gün sayısına göre çok daha düşüktür. Özet olarak, salgın sonuna kadar kısmi kapanma stratejisi hem vaka sayılarını azaltmada hem de tam kapanma sonucunda oluşan yüksek kapalı okul/iş yeri gün sayısının düşürülmesi için daha etkili bir yöntemdir. Bununla beraber hangi strateji uygulanırsa uygulansın, mümkün olduğunca erken başlamak, vaka sayılarının azaltılmasında önemli bir rol oynamaktadır.

Birçok benzetim modelinde olduğu gibi modelimizde de kompleksliği azaltıp, işlem sürelerini düşürmek için bazı basitleştirmeler ve ön kabuller yapılmıştır. A $\breve{g}$ modelinde bireylerin diğer bireylerle etkileşime girdiği çevre ev, okul ve iş yeri olarak düşünülmüş, toplu taşıma araçları, alışveriş merkezleri, restoran, kafe gibi bireylerin sosyalleștiği diğer mekanlar ihmal edilmiştir. Hastalık bulaştırma olasılıkları, kişinin yaş, cinsiyet, meslek vb. durumlarından bağımsız olarak, her birey için eşit kabul edilmiştir. Ayrıca hastalığın ilerleme dinamiklerini modellemek için basit SIR (Korunmasız-Hasta-İyileşmiş) modeli kullanılmıştır. Bu modelde asemptomatik olup hastalığ1 yayabilecek hastalar veya hastalığ 1 atlattıktan sonra tekrar hasta olabilecek bireylere yer verilmez.

Gelecek çalışmalarda, sadece kapanma stratejileri değil, aşılama ve antiviral ilaçların kullanılması gibi diğer müdahale stratejileri de içeren senaryoların test edildiği, en düşük vaka sayılarını ve ekonomik maliyetin amaçlandığı benzetim optimizasyonu yöntemleri geliştirilebilir.

\section{Yazar(lar)ın Katkıları}

MD çalışmaları yapmış ve makalenin yazımını gerçekleştirmişlerdir. Yazar makalenin son halini okudu ve onayladi.

\section{Çıkar Çatışması}

Yazar(lar), çıkar çatışması olmadığını beyan eder.

\section{Kaynaklar}

[1]. Demirbilek M., "YAYsim: Salgın Modelleme ve Karar Destek Sistemi”, Bilecik Şeyh Edebali Üniversitesi Fen Bilim. Derg., 2020, 7(1): 104-112.

[2]. Worldometers.info, https://www.worldometers.info/coronavirus/, 1 Mart 2020.

[3]. Dong E., Du H., and Gardner L., "An interactive web-based dashboard to track COVID-19 in real time", Lancet Infect. Dis., 2020, 20(5): 533-534.

[4]. Atalan A., "Is the lockdown important to prevent the COVID-9 pandemic? Effects on psychology, environment and economy-perspective" Ann. Med. Surg., 2020, 56: 38-42.

[5]. Maria, N., Zaid, A., Catrin, S., Ahmed, K., Ahmed, A. J., Christos, I., ... \& Riaz, A., "The socio-economic implications of the coronavirus pandemic (COVID-19): A review.", International Journal of Surgery, 2020, 78: 185-193.

[6]. Karataş M., "COVID-19 Pandemisinin Toplum Psikolojisine Etkileri ve Eğitime Yansımaları" J. Turkish Stud., 2020, 15(4): 1-13. 
[7]. Ourworldindata.info, https://ourworldindata.org/covid-school-workplace-closures/, 1 Mart 2020.

[8]. Keskin M. ve Özer Kaya D., “COVID-19 Sürecinde Öğrencilerin Web Tabanlı Uzaktan Eğitime Yönelik Geri Bildirimlerinin Değerlendirilmesi”, İzmir Kâtip Çelebi Üniversitesi Sağlık Bilim. Fakültesi Derg., 2020, 5(2): 59-67.

[9]. Kermack W. O. and McKendrick A. G., "A Contribution to the Mathematical Theory of Epidemics”, Proc. R. Soc. A Math. Phys. Eng. Sci., 1927, 115(772): 700-721.

[10]. Hethcote H. W., "The mathematical models of diseases", 2000, 42(4): 599-653.

[11]. Medlock J. and Galvani A. P., "Optimizing influenza vaccine distribution", Science, 2009, 325(5948): 1705-1708.

[12]. Craig B. R., Phelan T., Siedlarek J. P., and Steinberg J., "Improving Epidemic Modeling with Networks", Econ. Comment. (Federal Reserv. Bank Cleveland), 2020, 1-8.

[13]. Calvó-Armengol A. and Jackson M. O., "Networks in labor markets: Wage and employment dynamics and inequality", J. Econ. Theory, 2007, 132(1), 27-46.

[14]. Chaney T., "The network structure of international trade", American Economic Review, 2014, 104(11): 3600-3634.

[15]. Elliott M., Golub B., and Jackson M. O., "Financial networks and contagion", American Economic Review, 2014, 104(10): 3115-3153.

[16]. Walters C. E., Meslé M. M. I., and Hall I. M., "Modelling the global spread of diseases: A review of current practice and capability", Epidemics, 2018, 25: 1-8.

[17]. Prieto D. M., Das T. K., Savachkin A. A., Uribe A., Izurieta R., and Malavade S., “A systematic review to identify areas of enhancements of pandemic simulation models for operational use at provincial and local levels", BMC Public Health, 2012, 12(1): 251.

[18]. Knipl D. H. and Röst G., "Modelling the strategies for age specific vaccination scheduling during influenza pandemic outbreaks", Math. Biosci. Eng., 2011, 8(1): 123-139.

[19]. Matrajt L. and Longini I. M., "Optimizing vaccine allocation at different points in time during an epidemic", PLoS One, 2010, 5(11): 1-11.

[20]. Lee S., Golinski M., and Chowell G., "Modeling Optimal Age-Specific Vaccination Strategies Against Pandemic Influenza", Bull. Math. Biol., 2012, 74(4): 958-980.

[21]. Shim E., "Prioritization of delayed vaccination for pandemic influenza", Math. Biosci. Eng., 2011, 8(1): 95-112.

[22]. Chao D. L., Halloran M. E., Obenchain V. J., and Longini I. M., "FluTE, a publicly available stochastic influenza epidemic simulation model”, PLoS Comput. Biol., 2010, 6(1): 1-8.

[23]. Hladish T., Melamud E., Barrera L. A., Galvani A., and Meyers L. A., "EpiFire: An open source C++ library and application for contact network epidemiology", BMC Bioinformatics, 2012, 13(76): 1-12.

[24]. Liu S., Poccia S., Candan K. S., Chowell G., and Sapino M. L., "EpiDMS: Data management and analytics for decision-making from epidemic spread simulation ensembles", J. Infect. Dis., 2016, 214: 427-432.

[25]. V.D. Broeck W., Gioannini C., Gonçalves B., Quaggiotto M., Colizza V., and Vespignani A., "The GLEaMviz computational tool, a publicly available software to explore realistic epidemic spreading scenarios at the global scale", BMC Infect. Dis., 2011, 11(37): 1-14.

[26]. Grefenstette, J. J., Brown, S. T., Rosenfeld, R., DePasse, J., Stone, N. T., Cooley, P. C., ... \& Burke, D. S., "FRED (A Framework for Reconstructing Epidemic Dynamics): an open-source software system for modeling infectious diseases and control strategies using census-based populations.", BMC public health, 2013, 13(1): 1-14.

[27]. Demirbilek, M., "The Effect of School/Workplace Closures on COVID-19 Related Incidents.", Avrupa Bilim ve Teknoloji Dergisi, 2021, (23): 62-69. 